\title{
REMARKS ON CERTAIN SELECTED FIXED POINT THEOREMS - II
}

\author{
Santosh Kumar \\ Department of Mathematics \\ Inderprastha Engineering College, 63, Site IV, Surya Nagar Flyover Road, Shahibabad, \\ Ghaziabad (INDIA). \\ Corresponding Author E-Mail: sengar1@rediffmail.com
}

\begin{abstract}
Recent common fixed point theorems due to Kumar et al [8] and Jungck [11] are used to derive two common fixed point theorems for four finite families of mappings in complete and compact metric spaces respectively.
\end{abstract}

AMS (MOS) Subject Classification(2000) : Primary 54 H 25; Secondary 47 H 10.

Key Words and phrases: Compatible mapping, coincidentally commuting mappings, coincidence point, fixed point, common fixed point.

Let $\mathrm{R}^{+}$denotes the set of non-negative real numbers and $\mathrm{Y}$ be the family of mappings $\mathrm{f}$ from $\mathrm{R}^{+}$into $\mathrm{R}^{+}$such that

(i) $\mathrm{f}$ is non-decreasing

(ii) $\mathrm{f}$ is upper semi-continuous in each coordinate variables

(iii) $\mathrm{g}(\mathrm{t})=\mathrm{f}\left(\mathrm{t}, \mathrm{t}, \mathrm{a}_{1} \mathrm{t}, \mathrm{a}_{2} \mathrm{t}, \mathrm{t}\right)<\mathrm{t}$ where $\mathrm{g}: \mathrm{R}^{+} \rightarrow \mathrm{R}^{+}$is a mapping with $\mathrm{g}(0)=0$ and $\mathrm{a}_{1}+\mathrm{a}_{2}=2$.

We need to recall the following:

Definition 1 (Jungck and Rhoades [12])

Two maps $\mathrm{A}, \mathrm{S}: \mathrm{X} \rightarrow \mathrm{X}$ are said to be coincidentally commuting if they commute at their coincidence points.

The following fixed point theorem appears in Kumar et al [8].

Theorem 2 Let F, G, A and B be self-mappings of a metric space $(X, d)$ with $A(X) \subset$ $\mathrm{G}(\mathrm{X})$ and $\mathrm{B}(\mathrm{X}) \subset \mathrm{F}(\mathrm{X})$

(a) $[1+p d(F x, G y)] d(A x, B y)<p \max \{d(F x, A x) \cdot d(G y, B y), d(F x, B y) d(G y, A x)\}$

$+\mathrm{F}(\mathrm{d}(\mathrm{Fx}, \mathrm{Gy}), \mathrm{d}(\mathrm{Fx}, \mathrm{Ax}), \mathrm{d}(\mathrm{Gy}, \mathrm{By}), \mathrm{d}(\mathrm{Fx}, \mathrm{By}), \mathrm{d}(\mathrm{Gy}, \mathrm{Ax}))$

for all $x, y$ in $X$, FÎy with $p>0$.

If one of $A(X), B(X), G(X), F(X)$ is complete subspace of $X$, then

(b) $(\mathrm{A}, \mathrm{F})$ has a coincidence point.

(c) $(\mathrm{B}, \mathrm{G})$ has a coincidence point. 
Further if the pairs $(\mathrm{A}, \mathrm{F})$ and $(\mathrm{B}, \mathrm{G})$ are coincidentally commuting, then $\mathrm{A}, \mathrm{B}, \mathrm{F}$ and $\mathrm{G}$ have a unique common fixed point $\mathrm{z}$ which also remains the unique common fixed point of both the pairs separately.

As an application of Theorem 2, we derive a common fixed point theorem for four finite families of mappings which runs as follows:

Theorem 3 Let $\left\{\mathrm{S}_{1}, \mathrm{~S}_{2}, \ldots, \mathrm{S}_{\mathrm{m}}\right\},\left\{\mathrm{T}_{1}, \mathrm{~T}_{2}, \ldots, \mathrm{T}_{\mathrm{n}}\right\},\left\{\mathrm{I}_{1}, \mathrm{I}_{2}, \ldots, \mathrm{I}_{\mathrm{p}}\right\}$ and $\left\{\mathrm{J}_{1}, \mathrm{~J}_{2}, \ldots, \mathrm{J}_{\mathrm{q}}\right\}$ be four finite families of self - mappings of a metric space $(X, d)$ with $S=S_{1} S_{2} \ldots S_{m}$, $\mathrm{T}=\mathrm{T}_{1} \mathrm{~T}_{2} \ldots \mathrm{Tn}, \mathrm{I}=\mathrm{I}_{1} \mathrm{I}_{2} \ldots \mathrm{I}_{\mathrm{p}}$ and $\mathrm{J}=\mathrm{J}_{1} \mathrm{~J}_{2} \ldots \mathrm{J}_{\mathrm{q}}$ satisfying the following conditions:

(d) $\mathrm{S}(\mathrm{X}) \subset \mathrm{J}(\mathrm{X}), \mathrm{T}(\mathrm{X}) \subset \mathrm{I}(\mathrm{X})$

(e) one of $\mathrm{S}(\mathrm{X}), \mathrm{T}(\mathrm{X}), \mathrm{I}(\mathrm{X})$ and $\mathrm{J}(\mathrm{X})$ is a complete subspace of $\mathrm{X}$

(f) $[1+p d(F x, G y)] d(A x, B y)<p \max \{d(F x, A x) \cdot d(G y, B y), d(F x, B y) \cdot d(G y, A x)\}$

$+\mathrm{F}(\mathrm{d}(\mathrm{Fx}, \mathrm{Gy}), \mathrm{d}(\mathrm{Fx}, \mathrm{Ax}), \mathrm{d}(\mathrm{Gy}, \mathrm{By}), \mathrm{d}(\mathrm{Fx}, \mathrm{By}), \mathrm{d}(\mathrm{Gy}, \mathrm{Ax}))$.

Then

(g) $(\mathrm{S}, \mathrm{I})$ have a point of coincidence

(h) $(\mathrm{T}, \mathrm{J})$ have a point of coincidence.

Moreover, if $S_{i} S_{j}=S_{j} S_{i}, I_{k} I_{1}=I_{1} I_{k}, T_{r} T_{s}=T_{s} T_{r}, J_{t} J_{u}=J_{u} J_{t}, S_{i} I_{k}=I_{k} S_{i}$, and $T_{r} J_{t}=J_{t} T_{r}$ for all $\mathrm{i}, \mathrm{j} \in \mathrm{I}_{1}=\{1,2, \ldots, \mathrm{m}\}, \mathrm{k}, \mathrm{l} \in \mathrm{I}_{2}=\{1,2, \ldots, \mathrm{p}\}, \mathrm{r}, \mathrm{s} \in \mathrm{I}_{3}=\{1,2, \ldots, \mathrm{n}\}$ and $\mathrm{t}$, $\mathrm{u} \in \mathrm{I}_{4}=\{1,2, \ldots, \mathrm{q}\}$. Then (for all $\mathrm{i} \in \mathrm{I}, \mathrm{k} \in \mathrm{I}_{2}, \mathrm{r} \in \mathrm{I}_{3}$ and $\mathrm{t} \in \mathrm{I}_{4}$ ) $\mathrm{S}_{\mathrm{i}}, \mathrm{I}_{\mathrm{k}}, \mathrm{T}_{\mathrm{r}}$ and $\mathrm{J}_{\mathrm{t}}$ have a common fixed point.

Proof The conclusions (g) and (h) are immediate as S, T, I and J satisfy all the conditions of Theorem 2. Now appealing to componentwise commutativity of various pairs, one can immediately prove that SI $=\mathrm{IS}$ and $\mathrm{TJ}=\mathrm{JT}$ and hence obviously both the pairs $(\mathrm{S}, \mathrm{I})$ and $(\mathrm{T}, \mathrm{J})$ are coincidentally commuting. Note that all the conditions of Theorem 2. (for mappings $\mathrm{S}, \mathrm{T}, \mathrm{I}$ and $\mathrm{J}$ ) are satisfied ensuring the existence of unique common fixed point $z$. Now we need to show that $\mathrm{z}$ remains the fixed point of all component maps. For this consider

$$
\begin{aligned}
\mathrm{S}\left(\mathrm{S}_{\mathrm{i}} \mathrm{z}\right) & =\left(\left(\mathrm{S}_{1}, \mathrm{~S}_{2}, \ldots .,\right) \mathrm{S}_{\mathrm{i}}\right) \mathrm{z}=\left(\mathrm{S}_{1} \mathrm{~S}_{2} \ldots \mathrm{S}_{\mathrm{m}-1}\right)\left(\left(\mathrm{S}_{\mathrm{m}} \mathrm{S}_{\mathrm{i}}\right) \mathrm{z}\right)=\left(\mathrm{S}_{1} \ldots \mathrm{S}_{\mathrm{m}-1}\right)\left(\mathrm{S}_{\mathrm{i}} \mathrm{S}_{\mathrm{m}} \mathrm{z}\right) \\
& =\left(\mathrm{S}_{1} \ldots \mathrm{S}_{\mathrm{m}-2}\right)\left(\mathrm{S}_{\mathrm{m}-1} \mathrm{~S}_{\mathrm{i}}\left(\mathrm{S}_{\mathrm{m}} \mathrm{z}\right)\right)=\left(\mathrm{S}_{1} \ldots\right) \mathrm{S}_{\mathrm{i}}\left(\mathrm{S}_{\mathrm{m}-1}\left(\mathrm{~S}_{\mathrm{m}} \mathrm{z}\right)\right) \\
& =\left(\mathrm{S}_{1} \ldots \mathrm{S}_{\mathrm{m}-4}\left(\mathrm{~S}_{\mathrm{m}}-3 \mathrm{~S}_{\mathrm{i}}\right)\left(\left(\mathrm{S}_{\mathrm{m}-2}\left(\mathrm{~S}_{\mathrm{m}} \mathrm{z}\right)\right)\right)=\ldots=\left(\mathrm{S}_{\mathrm{i}}\left(\mathrm{S}_{1} \mathrm{~S}_{2} \ldots . \mathrm{S}\right) \mathrm{z}=\mathrm{S}_{\mathrm{i}}(\mathrm{Sz})=\mathrm{S}_{\mathrm{i}} \mathrm{z} .\right.\right.
\end{aligned}
$$

Similarly one can show that

$\mathrm{S}\left(\mathrm{I}_{\mathrm{k}} \mathrm{z}\right)=\mathrm{I}_{\mathrm{k}}(\mathrm{Sz})=\mathrm{I}_{\mathrm{k}} \mathrm{z}, \mathrm{I}\left(\mathrm{I}_{\mathrm{k}} \mathrm{z}\right)=\mathrm{I}_{\mathrm{k}}(\mathrm{Iz})=\mathrm{I}_{\mathrm{k}} \mathrm{z} . \mathrm{I}\left(\mathrm{S}_{\mathrm{i}} \mathrm{z}\right)=\mathrm{S}_{\mathrm{i}}(\mathrm{Iz})=\mathrm{S}_{\mathrm{i}} \mathrm{z}$

$\mathrm{T}\left(\mathrm{T}_{\mathrm{r}} \mathrm{z}\right)=\mathrm{T}_{\mathrm{r}}(\mathrm{Tz})=\mathrm{T}_{\mathrm{r}} \mathrm{z} . \mathrm{T}\left(\mathrm{J}_{\mathrm{t}} \mathrm{z}\right)=\mathrm{J}_{\mathrm{t}}(\mathrm{Tz})=\mathrm{J}_{\mathrm{t}} \mathrm{z} . \mathrm{J}\left(\mathrm{T}_{\mathrm{r}} \mathrm{z}\right)=\mathrm{T}_{\mathrm{r}}(\mathrm{Jz})=\mathrm{T}_{\mathrm{r}} \mathrm{z} . \mathrm{J}\left(\mathrm{J}_{\mathrm{t}} \mathrm{z}\right)=\mathrm{J}_{\mathrm{t}}(\mathrm{Jz})=\mathrm{J}_{\mathrm{t}} \mathrm{z}$ which show that (for all i, r, k and t) $S_{i} Z$ and $I_{k} Z$ are other fixed points of the pair (S, I)

whereas $T_{\mathrm{r}} \mathrm{z}$ and $\mathrm{J}_{\mathrm{i} Z} \mathrm{z}$ are the other fixed points of the pair $(\mathrm{T}, \mathrm{J})$. Now appealing to the uniqueness of common fixed points of the pairs $(\mathrm{S}, \mathrm{I})$ and $(\mathrm{T}, \mathrm{J})$ one gets (for all $\mathrm{i}, \mathrm{r}, \mathrm{k}$ and $t) z=S_{i} z=T_{r} z=I_{k} z=J_{t} z$ which show that $z$ is a common fixed point of $S_{i}, T_{r}, I_{k}$ and $\mathrm{J}_{\mathrm{t}}$ for all $\mathrm{i}, \mathrm{r}, \mathrm{k}$ and $\mathrm{t}$.

\section{Remark 4}

By setting $\mathrm{S}_{1}=\mathrm{S}_{2}=\ldots=\mathrm{S}_{\mathrm{m}}=\mathrm{A}, \mathrm{T}_{1}=\mathrm{T}_{2}=\ldots=\mathrm{T}_{\mathrm{n}}=\mathrm{B}, \mathrm{I}_{1}=\mathrm{I}_{2}=\ldots=\mathrm{I}_{\mathrm{k}}=\mathrm{F}$

and $J_{1}=J_{2}=\ldots=J_{t}=G$, we get a fixed point theorem for $A_{m}, B_{n}, F_{k}$ and $G_{t}$ which generalizes the Theorem 2 due to Kumar et al. [8]. In process several known results are 
generalized and improved (e.g. Theorem 2.3 [14]). More particularly by setting $\mathrm{m}=\mathrm{n}=\mathrm{p}$ $=\mathrm{q}$ and (for all $\mathrm{i}, \mathrm{r}, \mathrm{k}$ and $\mathrm{t}$ ) $\mathrm{S}_{\mathrm{i}}=\mathrm{T}_{\mathrm{r}}=\mathrm{I}_{\mathrm{k}}=\mathrm{J}_{\mathrm{t}}=\mathrm{F}$, we deduce a fixed point theorem for an iterates of $\mathrm{F}$ which presents a generalization to the theorem of Bryant [1].

Remark 5 By choosing f suitably one can derive improved versions of a multitude of relevant known common fixed point theorems involving four mappings especially those contained in Lal et al. [15], Singh-Meade [17], Husain - Sehgal [6], Khan - Imdad [14],

Jungck [9], Ciric [2], Singh - Singh [18], Fisher [4, 5], Das - Naik [3], Kannan [13], Rhoades [16] and several others. Also setting $p=0$ and choosing S, T, I, J and f suitably one can deduce the results proved in the above cited references and many others. Next we wish to indicate a similar result in compact metric spaces. For this purpose one can adopt a general fixed point theorem for commuting mappings in compact metric spaces due to Jungck [11], which was originally proved for compatible mappings (a notion due to Jungck [10]).

\section{Theorem 6 ([11])}

Let $\mathrm{A}, \mathrm{S}, \mathrm{I}$ and $\mathrm{J}$ be self-mapping of a compact metric space $(\mathrm{X}, \mathrm{d})$ with $\mathrm{A}(\mathrm{X}) \subset$ $\mathrm{J}(\mathrm{X})$ and $\mathrm{S}(\mathrm{X}) \subset \mathrm{I}(\mathrm{X})$. If the pairs $(\mathrm{A}, \mathrm{I})$ and $(\mathrm{S}, \mathrm{J})$ are commuting and

$\mathrm{d}(\mathrm{Ax}, \mathrm{Sy})<\mathrm{M}(\mathrm{x}, \mathrm{y})$, for all $\mathrm{x}, \mathrm{y}$ I $\mathrm{X}$

where $M(x, y)=\max \{d(I x, J y), d(I x, A x), d(J y, S y),[d(I x, S y)+d(J y, A x)] / 2\}$ with $\mathrm{M}(\mathrm{x}, \mathrm{y})>0$, then $\mathrm{A}, \mathrm{S}, \mathrm{I}$ and $\mathrm{J}$ have a unique common fixed point provided all four mappings $\mathrm{A}, \mathrm{S}, \mathrm{I}$ and $\mathrm{J}$ are continuous.

As an application of Theorem 6 one can have the following:

\section{Theorem 7}

Let $\left\{\mathrm{S}_{1}, \mathrm{~S}_{2}, \ldots, \mathrm{S}_{\mathrm{m}}\right\},\left\{\mathrm{T}_{1}, \mathrm{~T}_{2}, \ldots, \mathrm{T}_{\mathrm{n}}\right\},\left\{\mathrm{I}_{1}, \mathrm{I}_{2}, \ldots, \mathrm{I}_{\mathrm{p}}\right\}$ and $\left\{\mathrm{J}_{1}, \mathrm{~J}_{2}, \ldots, \mathrm{J}_{\mathrm{q}}\right\}$

be four finite families of self - mappings of a complete metric space $(\mathrm{X}, \mathrm{d})$ with

$\mathrm{S}=\mathrm{S}_{1} \mathrm{~S}_{2} \ldots \mathrm{S}_{\mathrm{m}}, \mathrm{T}=\mathrm{T}_{1} \mathrm{~T}_{2} \ldots \mathrm{T}_{\mathrm{n}}, \mathrm{I}=\mathrm{I}_{1} \mathrm{I}_{2} \ldots$ Ip and $\mathrm{J}=\mathrm{J}_{1} \mathrm{~J}_{2} \ldots \mathrm{J}_{\mathrm{q}}$ continuous mappings

satisfying (d) and $d(S x, T y)<M(x, y)$ for all $x, y \in X$ where $M(x, y)=\max \{d(I x, J y)$, $d(I x, S x), d(J y, T y), 1 / 2[d(I x, T y)+d(J y, S x)]\}$ with $M(x, y)>0$. Moreover if $S_{i} S_{j}=S_{j} S_{i}$, $\mathrm{I}_{\mathrm{k}} \mathrm{I}_{\mathrm{l}}=\mathrm{I}_{1} \mathrm{I}_{\mathrm{k}}, \mathrm{T}_{\mathrm{r}} \mathrm{T}_{\mathrm{s}}=\mathrm{T}_{\mathrm{s}} \mathrm{T}_{\mathrm{r}}, \mathrm{J}_{\mathrm{t}} \mathrm{J}_{\mathrm{u}}=\mathrm{J}_{\mathrm{u}} \mathrm{J}_{\mathrm{t}}, \mathrm{S}_{\mathrm{i}} \mathrm{I}_{\mathrm{k}}=\mathrm{I}_{\mathrm{k}} \mathrm{S}_{\mathrm{i}}$, and $\mathrm{T}_{\mathrm{r}} \mathrm{J}_{\mathrm{t}}=\mathrm{J}_{\mathrm{t}} \mathrm{T}_{\mathrm{r}}$ for all $\mathrm{i}, \mathrm{j} \in \mathrm{I}_{1}=\{1,2, \ldots$, $\mathrm{m}\}, \mathrm{k}, 1 \in \mathrm{I}_{2}=\{1,2, \ldots, \mathrm{p}\}, \mathrm{r}, \mathrm{s} \in \mathrm{I}_{3}=\{1,2, \ldots, \mathrm{n}\}$ and $\mathrm{t}, \mathrm{u} \in \mathrm{I}_{4}=\{1,2, \ldots, \mathrm{q}\}$, Then (for all $\mathrm{i} \in \mathrm{I}_{1}, \mathrm{k} \in \mathrm{I}_{2}, \mathrm{r} \in \mathrm{I}_{3}$ and $\left.\mathrm{t} \in \mathrm{I}_{4}\right) \mathrm{S}_{\mathrm{i}}, \mathrm{I}_{\mathrm{k}}, \mathrm{T}_{\mathrm{r}}$ and $\mathrm{J}_{\mathrm{t}}$ have a unique common fixed point.

Proof The proof is essentially the same as that of Theorem 3, hence it is omitted.

Remark 8 By setting $\mathrm{S}=\mathrm{S}_{1} \mathrm{~S}_{2}, \mathrm{~T}=\mathrm{T}_{1} \mathrm{~T}_{2}, \mathrm{I}=\mathrm{I}_{1}$ and $\mathrm{J}=\mathrm{J}_{1}$ in Theorem 3 and Theorem 7 one can deduce Theorem 1.2 and Theorem 1.4 of Imdad [7] respectively.

\section{REFERENCES}

1. V. W. Bryant, A remark on fixed point for iterated mappings, Amer. Math. Monthly, 75(1968),399 - 400.

2. Lj B. Ciric, Generalized contractions and fixed point theorems, Publ. Inst. Math., 12(26)(1971), 19-26. 
3. K. M. Das and K.V. Naik, Common fixed point theorems for commuting maps on a metric space, Proc. Amer. Math. Soc., 77(1979),369-373.

4. B. Fisher, Mappings with a common fixed point, Math. Sem. Notes, 7(1979),8184.

5. B. Fisher, Common fixed points of commuting mappings, Bull. Inst. Math. Acad. Sinica, 9(1981), 399 - 406.

6. S. A. Hussain and V. M. Sehgal, On common fixed points for a family of mappings, Bull. Austral. Math. Soc.,13(1975), 261- 267.

7. M. Imdad, Remarks on certain selected fixed point theorems, Internat. J. Math. Math. Sci., (in press).

8. Santosh Kumar and M. Imdad, A general common fixed point theorem without continuity, J. Indian Acad. Math., 27(2)(2005), 215 - 229.

9. G.Jungck, Commuting mappings and fixed points, Amer. Math., Monthly, 83 (1976), 261- 263.

10. G. Jungck, Compatible mappings and common fixed points, Internat. J. Math. Math. Sci., 9(4)(1986), 771 - 779.

11. G. Jungck, Common fixed points for commuting and compatible maps on compacta, Proc. Amer. Math. Soc., 103(3)(1988), 977- 983.

12. G. Jungck and B. E. Rhoades, Fixed point for set-valued functions without continuity, Indian J. Pure Appl. Math., 29(3)(1998), 227-238.

13. R. Kannan, Some results on fixed points, Bull. Cal. Math. Soc., 60(1968),71-76.

14. M. S. Khan and M. Imdad, Some common fixed point theorems, Glasnik Math. 18 (38) (1983), 321-326.

15. S. N. Lal, P. P. Murthy and Y. J. Cho, An extension of Telci, Tas and Fisher's theorem, J. Korean Math. Soc., 33(4) (1996), 891 - 908.

16. B. E. Rhoades, A comparison of various definitions of contractive mappings, Trans. Amer. Math. Soc., 226(1977), 257-290.

17. S. P. Singh and B. A. Meade, On common fixed point theorems, Bull. Austral. Math. Soc., 16 (1977), 49-53.

18. S. L. Singh and S. P. Singh, A fixed point theorem, Indian. J. Pure Appl. Math., 11 (1980), 1584-1586. 